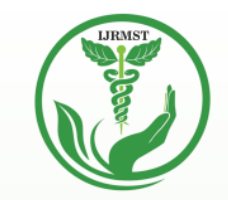

INTERNATIONAL JOURNAL OF RESEARCH IN MEDICAL SCIENCES \& TECHNOLOGY

e-ISSN:2455-5134; p-ISSN: 2455-9059

\title{
A COMPREHENSIVE ANALYSIS ON THE CRIME PATTERN IMPLEMENTATION AND DEVELOPMENT
}

\section{Laiba Rahman}

Sri Venkateswara College, University of Delhi, Delhi, India

Paper Received: 05 ${ }^{\text {th }}$ April, 2021; Paper Accepted: 20th May, 2021;

Paper Published: $2^{\text {th }}$ June, 2021

DOI: http://doi.org/10.37648/ijrmst.vl li01.012

How to cite the article:

Laiba Rahman, A Comprehensive

Analysis on the Crime Pattern

Implementation and Development,

IJRMST, January-June 2021, Vol 11, 132-139, DOI:

http://doi.org/10.37648/ijrmst.v11i01.012

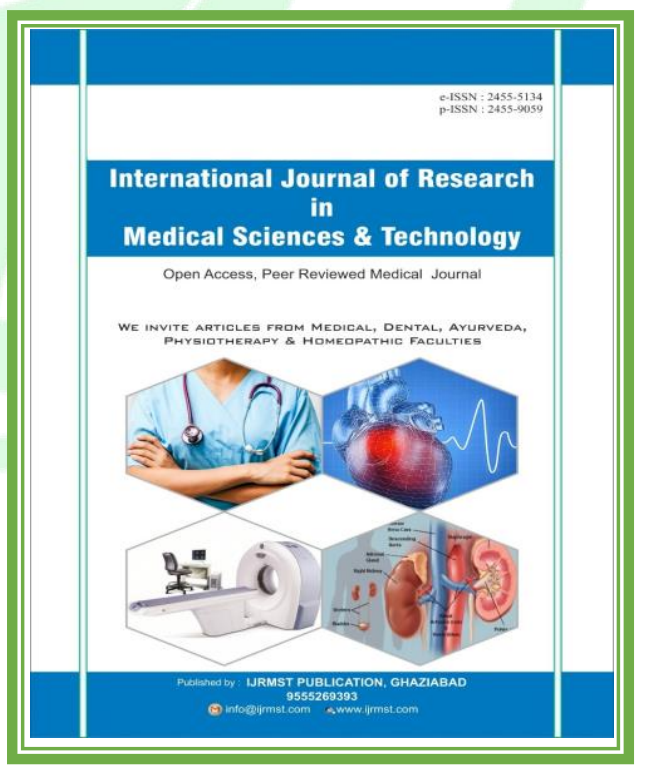




\begin{abstract}
Crime is a significant issue, where our management has given the full focus. Efficient analysis of various remote detecting methods is refined for crime examination. This exploration work proposes the use of short detecting systems to concentrate on Crime with the assistance of research devices. This paper extends a sign of the devices and procedures executed in the Crime with effective innovations dependent on remote detecting. The advances in doing the device have great temptation in the current changing crime circumstance. They can be used as a predominant device by law authorisation for crime investigation, recognition and prevention.
\end{abstract}

\section{INTRODUCTION}

Criminal science is a region that internal parts the logical investigation of the crime and unlawful conduct and law approval and is a set-up that hopes to understand crime qualities. (1) It is quite possibly the most basic field where remote detecting methodology can deliver basic outcomes. Crime analysis, a piece of criminal science, is an effort that consolidates researching and recognizing violations and their associations with criminals. Crime events are accounted for consistently is growing fundamentally (2). The Department of Police is the significant relationship of forestalling violations; finding a country without a crime-free society is incredibly difficult. The current local area has also been loaded with various types of crimes. The Police office controls further developing security; people generally advanced toward becoming good beings, keeping control and quiet.

\section{COMPONENTS OF CRIME}

Crime analysts have perceived a gathering of social, monetary, individual, and segment components and insights compute that sway crime percentage designs. Likely the main features observed.

\section{A. Biological}

In 1970, the pattern of XYY chromosomes sequence was published.The research shows that people with extra Y sequences in chromosomes are rude. Many surveys have not agreed to this research. But later, some research has proved that person with an XYY chromosome sequence has a winning attitude. This segment hence is the best-case scenario that proved the inclusion of crime. 


\section{VOLUME: 1 1, JANUARY-JUNE 2021}

\section{B. Cybercrime}

Web extortion alludes to the actual usage of Web designs to display beguiling deals to fast approaching setbacks, to lead to false trades. Email blackmail, impel cost distortion, feeling stunts, business stunts, and other phishing stunts are the most notable and most by and largely used kinds of premium extortion.

\section{Coordinated crime}

It is a social event of individuals, either close by, public or worldwide, who partake in criminal benefits. The premise behind why they have outlined movements since they may be politically persuaded, monetarily spurred or an organized group of thugs.

\section{Property related misconduct}

Property related misconduct joins infringements that are not facilitated, especially at unmistakable people. Or then again, perhaps, these infringements are a way for the property. With propertyrelated misconduct, it may separate the property, or the parcel may be harmed in one way or another. Typically, people are not hurt since the assumption is consistently focused on getting or destroying the property. However, individuals may be harmed, as in firerelated crimes.

\section{E. Destitution and unemployment}

Most records checking out the association between neediness, joblessness, and wrongdoing have investigated crime percentages in locales put aside by poverty and joblessness rather than paces of collaboration in misconduct by poor or jobless individuals [10]. The issue with this sort of exploration is that, in retirement, it can't tell us whether it is poor individuals and jobless who are executing the crimes.

\section{DIFFICULTIES AND APPROACHES}

The most brain staggering test for the police officer is inspecting crimes as they progress. Police association has been taken care of in any place, care of colossal proportion of information and the tremendous volume of records. They require constrained developments to manage wrongdoing. An ideal wrongdoing affirmation structure should [11]. Be used to perceive wrongdoing designs quickly for future crime design recognition and action. Remote detecting techniques can help disclose realities. During the time spent remote detecting, the most basic step is Geospatial detecting.

Effective mindfulness is to develop a crime assessment and planning framework that helps the police team. 


\section{VOLUME: 1 1, JANUARY-JUNE 2021}

1. Recognizing violations expectations and performing wrongdoing investigation.

2. Give information and Geospatial preliminary outcomes to characterize frameworks for wrongdoing evasion and decrease.

3. Recognize and examination, real wrongdoing examples to decrease advance occasions of equivalent recurrence.

\section{DATASET}

\section{A. Regulatory Crime Analysis}

Managerial wrongdoing examination oversees long to broaden assessments (quarterly, semi-consistently or each year).[15] Cases of definitive bad behaviour examination endeavours consolidate giving money related, geographic, and law authorization information to a police organization, City Organization, City Board, and neighbourhood/subject get-togethers.

\section{B. Key Crime Analysis}

Key wrongdoing examination is worried about functional procedures besides searches for serious consequences regarding advancing issues [12]. The justification behind imperative bad behaviour examination is to perform police advantage even more feasibly and capably by coordinating with advantage transport

to demands for the organization.

\section{Strategic Crime Analysis}

Strategic wrongdoing examination oversees fast illicit offences (speedy, hours, days, or long stretches of the period of the wrongdoing). It propels a quick response to new crimes, robberies and burglaries.[10] The essential bad behaviour examination gives information to assist the functional labour force distinguish bad behaviour designs and the catch of blameworthy criminal gatherings.

a) Data utilized

Day by day, recorded wrongdoing information is utilized for review. The gathered informational collection gives the accompanying:

Area of the wrongdoing

Sorts of wrongdoing

Area of interest recognition

Examination of the protected zone places

Geospatial data

TECHNIQUES AND TOOLS FOR ANALYSIS OF CRIME IN REMOTE SENSING

Detection of remote location to find GIS based data. There are famous devices and 


\section{VOLUME: 1 1, JANUARY-JUNE 2021}

methods used, and there are different small detecting strategies accessible as follows.

\section{A.Hotspot examination}

The $\mathrm{X}$ and $\mathrm{Y}$ geocode coordinates of destructed data is marked as singular points in the dataset. Past these Coordinates, each issue has different properties portraying the hour of the wrongdoing. [10] Hotspot examination is assessed to recognize regions that are described by a higher wrongdoing

thickness than other regions.

A problem area is a field that Receives more noteworthy than the conventional worth of wrongdoing issues. In this manner, the Hotspot is characterized by Sherman (1995) As a little Place where a criminal offence is entirely continued, to the point that it is exceptionally unsurprising, basically more than one year.

\begin{tabular}{|l|l|}
\hline Digital Techniques & $\begin{array}{l}\text { Remote sensing Techniques and } \\
\text { Tools }\end{array}$ \\
\hline Hotspot analysis & $\begin{array}{l}\text { Interpolation method Cluster } \\
\text { analysis, OGIS }\end{array}$ \\
\hline Crime analysis & Kernel -Density estimation \\
\hline Crime mapping & $\begin{array}{l}\text { Inverse distance weighted and } \\
\text { Gefis-od Gi* }\end{array}$ \\
\hline $\begin{array}{l}\text { Hotspot / safe zone } \\
\text { analysis }\end{array}$ & \begin{tabular}{l} 
Linear interpolation method \\
\hline Assessment of \\
crime
\end{tabular} \\
\hline
\end{tabular}

\section{B. Kernal Density Estimation}

The piece thickness itself works out size for every unit space of direct wrongdoing component utilizing a bit of work toward fit an easily tightened surface. A similar technique, the bit thickness smoothing, was likewise used for the wrongdoing safe zone planning [7] [8]. Problem area examination is refined by changing the discrete direct dissemination of crime locations toward a continuous surface of crime location thickness. This method ascertains a matrix whose cell esteems address thickness esteems identified with a specific surface measure dependent on a given point dataset. 


\section{Direct Interpolation Method}

The straightforward introduction strategy gives an adaptable construction, and a bunch of $\mathrm{n}$ focuses handled in the plane. The exploratory survey by applying RBF suggests that the exactness of wrongdoing planning is being extended. [10] The Quantum Geographic Information System (QGIS) device is used to imagine, investigate, control, and separate Geopractical wrongdoing datasets.

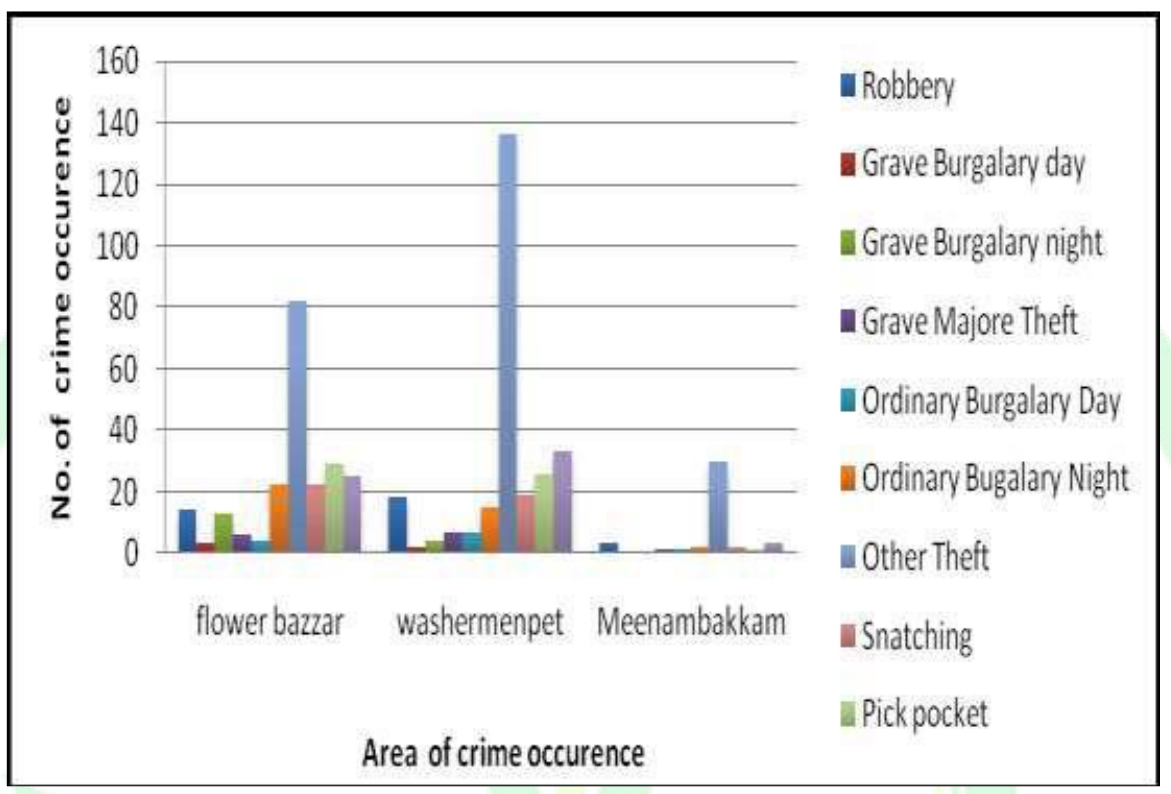

Fig: 1Property crime over the period of three years in Chennai city

\section{CONCLUSION}

This paper investigates the strategies executed in remote detecting by utilizing wrongdoing information. Here examined wrongdoing essential and auxiliary data set what's more, given the insights regarding where to get information assets. Kinds of mischief and elements of violations how it took care of by remote detecting device. It is extremely helpful to recognize wrongdoing designs and break down wrongdoing examination, and it diminishes the other event of comparative occurrences. It figures methodologies for wrongdoing anticipation and derivation. 


\section{VOLUME: 1 1, JANUARY-JUNE 2021}

\section{REFERENCES}

[1]. S.Sivaranjani and S.Sivakumari, 2015 "GISbased crime hotspot mapping and analysis usingradial basis function and interpolation method",International Journal of Remote Sensing\&Geoscience (IJRSG), Volume 4, Issue 5,

[2]. Thangavelu A., Sathyaraj S.R., andBalasubramanian S. "Assessment of SpatialDistribution of Rural Crime Mapping in India":A GIS Perspective Cloud PublicationsInternational Journal of Advanced RemoteSensing and GIS 2013, Volume 2, Issue 1, pp.70-85, Article ID Tech-62 ISSN 2320 - 0243.

[3]. Adepoju M. O, Halilu S. A, S.O. Mohammed, Ozigis S. M, Idris I, Blessing A, Adeluyi O. 2014. "A geo-spatial technologies for Nigerian urban security and crime management" - a study of Abuja crime hotspot mapping and analysis ASPRS.

[4]. White, J.L., Moffit, T.E., Earls, F., Robins, L. \& Silva, P.A. 1990, „How early can we tell: Predictors of childhood conduct disorder and adolescent delinquencye ${ }^{e e}$ Criminology, vol. 28 , no. 4 , pp. 507-528.

[5]. Jitendra Kumar, Sripati Mishra, Neeraj Tiwari "Identification of Hotspots and Safe Zones of Crime in Uttar Pradesh, India: Geo-spatial Analysis Approach" International Journal of Remote Sensing Applications IJRSA, IJRSA Vol.2 No.1 2012 PP.15-19.

[6]. M.Ramzan Begam, Dr. P.Sengottuvelan T. Ramani Survey: Tools and Techniques implemented in Crime Data Sets, IJISET - International Journal of Innovative Science, Engineering \& Technology, Vol. 2 Issue 6, June 2015.

[7]. Lenin Barath Kumar.D, Selvavinayagam.k, SureshBabu.S "Assessment of Crime \& its Mapping Using Remote Sensing \& 3D Geo-Spatial Model for Chennai City" International Journal of Engineering Trends and Technology" (IJETT) - Volume 9 Number 8 - Mar 2014.

[8]. Shahebaz M. Ansari, Dr. K. V. Kale "Mapping and Analysis of Crime in Aurangabad City using GIS" IOSR Journal of Computer Engineering (IOSR-JCE) e-ISSN: 22780661,ISSN: 2278-8727, Volume 16, Issue 4, Ver. VII (Jul - Aug. 2014), PP 67-76.

[9]. Kiwon Lee, uses of open source remote sensing software for interoperable geo-web implementation International Archives of the Photogrammetry, Remote Sensing and Spatial Information Science, Volume XXXVIII, Part 8, Kyoto Japan 2010 


\section{VOLUME: 11 , JANUARY-JUNE 2021}

[10]. M. Ahmed and R. S. Salihu, "Spatiotemporal Pattern of Crime Using Geographic Information System (GIS) Approach in Dala L.G.A of Kano State, Nige-ria”, American Journal of Engineering Research (AJER), Vol.2,(2012), Issue-3, pp-51-58.

[11]. Robert E. Roth, Kevin S. Ross, Benjamin G. Finch, Wei Luo, Alan M. MacEachren "Spatiotemporal crime analysis in U.S. law

enforcement agencies: Current practices and unmet needs" Government In-formation Quarterly, vol. 30 (2013), pp. 226-240.

[12]. Elizabeth R. Groff and Nancy G. La Vigne, "Fore-casting The Future Of Predictive Crime Mapping”, Crime Prevention Studies, volume 13, pp.29-57.

[13]. Giles C Oatley, Brian W Ewart, “Crimes analysis software: „pins in mapse, clustering and Bayes net prediction”, Expert Systems with Applications, 2003 - Elsevier.

[14]. A.Rupali R.Surase, B.Karbhari V.Kale, "Performance evaluation of support vector machine and maximum likelihood classifier for multiple crop classification", International Journal of Remote Sensing \& Geosci-ences (IJRSG), 2015.

[15]. Christos G.Karydas,Ioannis Z.Gitas, Eirini Koutsogiannaki, Nikolaos LydakisSimantiris and Georgios N. Silleos, 2009 "Evaluation of spatial interpola-tion techniques for mapping agricultural topsoil prop-erties in crete” EARSeL eProceedings 